speak with real knowledge ; but those few who were honoured with his intimacy, those few who probed beneath the rugged surface-they know what a jewel lay hid for those who cared to seek, and to-day hold the memory of his friendship as the most sacred possession of their lives.

It is not inappropriate to sum up this slight tribute to his memory with a few lines from his well-known "Kasidah " :-

True to thy Nature, to Thyself, Fame and Disfame nor hope nor fear ;

Enough to thee the small still voice aye thund'ring in thine inner ear.

$* \quad * \quad * \quad * \quad * \quad * \quad *$

This "I" may find a future Life, a nobler copy of our own,

Where every riddle shall be ree'd, where every knowledge shall be known;

N. M. Penzer.

\title{
Maulvi Shaikh Laiqahmad Ansari, M.A.S.B., M.R.A.S.
}

The late Maulvi Shaikh Laiqahmad Ansari, an Oriental scholar of Delhi, came of the family of Shaikh Ansarian of Kairana (U.P.).

Mr. Ansari was for inany years on the Staff of the Morning Post of Delhi. He was the author of the Urdu Self Instructor and Idiomatic Urdu for Public Speeches, and was a warded a grant from the Government of the Punjab for the first-named publication, which has been pronounced as most useful by prominent educational authorities. The second book was dedicated by permission to the late Lord Minto, when Viceroy of India, and Mr. Ansari received autograph letters from Lord Ampthill and Sir James Latouche eulogizing the book.

His brilliant scholarship won for him a great reputation in the country, and he was sent on a deputation to Calcutta by Her Highness the Begum of Bhopal in connexion with research work.

Nazeer Ahmad Ansari. 